\title{
Writing the Present: Notation in Barthes's Collège de France lectures
}

\author{
Michael Sheringham \\ All Souls College, University of Oxford \\ Oxford 0X1 4AL, United Kingdom \\ e-mail: michael.sheringham@all-souls.ox.ac.uk
}

\begin{abstract}
In his lectures at the Collège de France in 1978-1979, Barthes focuses at length on the activity of 'la notation' (in English, notation): grabbing a fleeting event or impression as it happens, and registering it in your notebook. This article explores the ramifications of notation, as outlined in the lectures (where it is associated with haiku, Joycean epiphany and Proustian impressionism), linking it to Barthes's longstanding interest in the ontology of modes of signification. Allied to his concept of the 'third meaning', and to later terms such as the incident and the romanesque, notation is seen to be central to the preoccupation with affect, subjectivity and individuality we associate with Barthes's later work. Linked with the fantasy of writing a novel, notation also chimes with the "fantasmatic pedagogy" of Barthes's lectures where ideas are explored in a highly personal way through the accumulation of discontinuous traits. Through notation the affect-driven, decentred Barthesian subject finds its voice.
\end{abstract}

In his penultimate set of lectures at the Collège de France in 19781979, the first year of the two-year course he devoted to $L a$ Préparation du roman (Barthes 2003; Preparing for the Novel), ${ }^{1}$ Barthes focuses at length on the notion or activity of 'la notation' (hereafter, in English, notation). Its sphere of application is everyday life, the ambient world from which the would-be novelist is deemed to derive his materials. In the simplest terms notation consists in grabbing a fleeting event or impression quickly, on the wing, as it

1 "Preparing for the Novel" is as yet untranslated into English. The title and all other citations are given in my own translation. 
happens, and registering it in your notebook. Notation is inseparable from the kinds of things that prompt it, which Barthes calls notanda: not big, heavy, ponderous things, or meanings that need to be worked at or worked out; but little stray things, linked to moods, whims, transience, banality, circumstance.

I want to explore the ramifications of notation - as concept and activity - in the context of the Collège de France lectures, but also in the wider context of Barthes's work. 'La notation', I will argue, is at the core of late Barthes and thus central to one of the many 'Barthes' who are still so relevant today: the Barthes of affect, of subjectivity, of the body, and so forth. Notation ties in with the exploration of photography in Camera Lucida, as well as with Barthes's concepts of the incident and the romanesque. But I also want to suggest how notation - the values and affects it stands for - is a perennial feature of Barthes's writing and sensibility and of his theoretical endeavour. Writing to his friend Georges Perros on 11 April 1961 Barthes congratulated him on his Papiers collés, a book consisting of a series of disconnected notes and observations on everyday life, literature and philosophy. Praising the way Perros's non-fictional writing captured reality in a new way Barthes wrote: "it's extraordinary that it should be possible to tap in (capter) by means of something other than the imaginary. But in the end what you write is always half-way between dreaming and thinking" (Barthes 1988: 107). Perros went on to develop his art of notation and annotation in two further volumes of Papiers collés (which bear this text on their back covers: "decisively, lazily, haphazardly, Georges Perros notes. Bits and pieces; explosions, rages, despair, quiescence, in response to moods, to books, to places, in short the way we all live: in moments, flashes, dazzles" (Perros 1961: back cover). Barthes's enthusiasm for his friend's cult of the note and the fragment as a way of catching fleeting experience clearly made a deep impression on him.

One of the things that led Barthes towards linguistics and semiology was his fascination for the different ways in which meanings are articulated. But perhaps his central contribution to the convergence of the linguistic and the literary lay in his interest in the affective or existential dimension of meaning production and reception. Barthes is always interested in the effect certain forms of meaning production had on him. He is less concerned with what meanings mean (message), or how meanings mean (code), than with the affective 
impact of certain processes of meaning. In this affective economy, less is generally more: Barthes is led to the minutiae of meaning, what happens in the gaps between obvious meanings. In a famous text of 1970 he talks about the 'third meaning': not the first, the message, or the second, the symbolic or connotative level, but the third meaning, which he labelled obtuse, because of its wide compass, and also because it is the meaning that is only there in the first instance for the singular, embodied, individual - not the intellectual subject but the obtuse one, the idiot in us (Barthes 2002, III: 485-506). And of course we find a similar distinction in Camera Lucida between the studium, the obvious meaning of a photograph, the one we are supposed to see, and the punctum, the stray detail that makes an impact on me here and now when I look at the image (Barthes 2002, V: 785-894 passim).

Even in his out and out semiological phase, in The Fashion System for example, Barthes is interested in the existential dimension of the modes of signification he progressively taps into as he develops his analyses in various fields. ${ }^{2}$ Already in Writing Degree Zero he is haunted by the allure of a mode of signification, an écriture, that would be a sort of degree zero, a 'white writing' that would elude ready-made ideology. Mythologies is concerned with the heavyhandedness of ideology, as it manifests itself in operations of meaning production that were current in the mass media of the 1950s. If Barthes spent much time looking at the opposite of what appealed to him in the sphere of meaning, this was partly because the third meaning, the punctum, the notandum - the thing grasped by notation - whilst being very real, is associated with what is concrete, and therefore very hard to grasp, or to found anything on. Increasingly, the forum for Barthes's semiology became not the literary work but the city street, not the page but what he called "the page of life itself", and "the live writing of the street" (Barthes 2002, III: 412). Hence, in late Barthes we are dealing more and more explicitly with ways of living, lifestyles, art de vivre. Like Michel Foucault in the same period, Barthes moved towards the "care of the self", a search for a posture, a way of being in the world.

2 See "Barthes and the Everyday" in Sheringham 2006. 
Barthes's account of 'la notation' (which in French means the activity of noting things down and not, as more commonly in English, a script or idiom for doing so) occurs primarily in the set of lectures he delivered at the Collège de France in 1978-1979. Following his election, thanks to Foucault, to a chair in literary semiotics at the Collège in 1977, the challenge for Barthes was to adapt the form of teaching he had evolved at the Ecole des hautes études, where the staple was the seminar, to the format of the ex cathedra lecture. In his inaugural lecture at the Collège, titled Lesson, Barthes announced that his aim was to provide what he called a 'fantasmatic teaching', of a fragmentary and digressive kind. He would, he told his audience, explore, over the thirteen weeks of the series, the ramifications of a fantasy. And over the next four years, until just two days before he was fatally injured in a street accident, Barthes delivered four remarkable sets of lectures in which he combined intensely personal and idiosyncratic preoccupations with immensely wide literary and philosophical reference points. In his lectures, Barthes is always present as a singular human being, speaking in the first person, with specific memories and desires. The quest he embarks on each year is seen to have a bearing on the direction of his own life, and events such as the death of his mother, or his desire to adopt a new kind of writing perhaps a sort of novel - are incorporated into his endeavour.

Barthes devoted his first series of annual lectures to the question of "How to live together?", exploring, via the resonances of a single concept, that of idiorhythms, the best balance between being on one's own and living with others. His second series took 'The Neutral' as its central focus. In December 1978, Barthes told his audience that he was now embarking on a longer-term project that might occupy him for a number of years. Having reminded them of his commitment to human subjectivity after its obliteration by orthodox philology, by Marxism, and by certain kinds of structuralism - "better the blinds of subjectivity", he observed, "than the impostures of objectivity. Better the imaginary of the subject than its censorship" (Barthes 2003: 25) Barthes set out his most personal fantasy yet: that of making a radical change in his life and deciding to write some sort of novel.

The title of Barthes's last course is ambiguous: the preparation 'of' or 'for' the novel refers to his own process of working out what sort of 
novel he might write (he explains that he has not yet acted on his lifechanging fantasy), but also to what he has gleaned from his consideration of two key aspects or stages of how other novelists prepare for the novels they are to write. The first step or stage is to effect the transition "from life to work" (the sub-title of the first set of lectures). Taking it as evident that novelists draw on their own observations of life (not necessarily autobiographical but experiential) Barthes is concerned in the first lecture course with how the novelist collects and processes the materials out of which the work will be made. And it is here that the activity of notation will be central. In the second set of lectures, subtitled "the work as will", Barthes considers how writers take the next step: how they convert the desire to write a novel into novel-writing itself. Drawing on the letters, diaries, and plans of a number of writers, including Chateaubriand, Balzac, Flaubert, Proust and Kafka, Barthes considers the kind of life the writer chooses to live in order to make writing possible.

How does the activity of notation fit into Barthes's conception - or more accurately his fantasy - of 'Preparing for a novel'? Barthes explains that his fantasy springs from particular novels, above all Proust, but also Tolstoy's War and Peace, and he asserts that for him the novel is always in some sense affirmative. But if the novel is a generous genre, its way of celebrating experience often depends on memory, on preserving a cherished past. This does not, however, fit Barthes's fantasy because, he tells us, he suffers from a poor memory. Apart from brief flashes (as illustrated by the 'anamneses' sequence of Barthes by Barthes, which consists in fact of a series of rapid notations; Barthes 2002, IV: 836-847), he has no long-term memory, and does not dwell upon or seek to reconstitute his past. Perhaps then the novel is not for him, despite his fantasy?

To avoid this impasse Barthes steers his meditation round to the view that the kind of novel he might write would have to be charged by other energies, that can also be found in the novels he likes, and charged above all by the fact that underlying these novels is what he takes to have been the author's profound engagement with his own present, at least prior to the start of composition. For Barthes tells us 
that his own affective link is not with his past but always with the present, his present "in its affective, relational, and intellectual dimensions" (Barthes 2003: 45).

But the present is what is right there, at the end of one's nose. How can one reconcile this proximity with the distance implied by the kind of enunciation that characterises writing and particularly novel writing? If Barthes is convinced that the novelists he admires shared his conviction that literature is always "made from life", it is also clear to him that life is always present life. Hence, for him, preparation for the novel refers to "grasping that parallel text, the text of "contemporary', concomitant life" (Barthes 2003: 45). If he believes - and this is what he will seek to demonstrate throughout his discussion of notation - that one can "write the present by noting it — as it "falls" on you or under you (before your eyes or in your ears)" (Barthes 2003: 45), he is less clear about whether you can make a novel out of such present writing. For it may be that the novelists he admires have, at a certain stage, made the transition from life to work, have transformed "present writing" into novelistic form, have gone from the discontinuity, the fragmentariness, of notation, to the continuity of narrative structure. This may be what happened, in Proust's case, when Contre Sainte-Beuve turned into A la recherche du temps perdu: Barthes is obsessed with this hypothetical moment which he links to the death of Proust's mother, just as his own decision to write a novel was linked to the death of his own mother.

The issue then might be, Barthes surmises, whether in fact he is searching for a 'third form', a sort of hybrid 'novel through fragments'. To investigate this he decides to look at two seemingly diametrically opposed ways of incorporating the notation of the present into literature: on the one hand the mode of extreme brevity enacted in the Japanese poetic form of haiku; and on the other hand the profuse writing by which Proust converted his own life into the endless flowing sentences of $A$ la recherche.

Interestingly, Barthes says that to illustrate the activity of noting the present he could have focused on writers' notebooks or biographical diaries (Barthes 2003: 47). Why did he choose haiku? One answer is that Barthes's passion for haiku, which had arisen a decade earlier through his visits to Japan from 1966 onwards, had always been associated with the idea of writing the present. At the core of Empire of Signs - Barthes's book on Japan, or as he puts it, his book 
about a fantasy country he calls Japan, which has a series of short fragmentary essay on aspects of everyday life in Tokyo - are four key fragments devoted to haiku. Initially he focuses on the way westerners tend to want forcibly to inject meaningfulness into haiku, ignoring the fact that, according to Barthes, the Japanese see haiku as a "practice aimed at bringing language to a halt $[\ldots]$ breaking $[\ldots]$ the inner recitation that constitutes our person [...] working on the very root of meaning" (Barthes 2002, III: 408). Switching in his characteristic way from modes of signification to the field of lived experience, Barthes sees the particular semantics of haiku as the touchstone of a particular quality of event, the 'incident', where it is not what happens but the fact of happening that counts.

Transposed onto "the page of life", haiku, as incident, has the quality of a "light fold", as it is rapidly read "in the live script of the street" (Barthes 2002, III: 408). Haiku is associated with "an awakening before the fact of the event" (Barthes 2002, III: 410). "Haiku isn't a rich thought reduced to a brief form; it is a brief event that has found its appropriate form" (Barthes 2002, III: 411). Rather than reminding us of something in the past, haiku "probes the memory of what has not happened to us: it makes us recognise a repetition without origin, memory without persons, speech without moorings" (Barthes 2002, III: 412). For Barthes haiku is of a piece with "any discontinuous trait, any incident in Japanese life as it offers itself for me to read", and points in the direction of an equivalent way of living, "a graphic mode of existence" (Barthes 2002, III: 415), where human agency is enshrined in micro-gestures that are akin to delicate brushstrokes. Haiku suspends meaning and prompts the response: "that's right, that's exactly it", where 'it' isn't something special, a hidden meaning, something symbolized by the event, but is the event itself (Barthes 2002, III: 415).

In his account of notation Barthes devotes many pages to haiku. But because he sees it as epitomising the act of notation as writing the present, he in fact progressively builds up a set of traits, properties or parameters that are of far wider application. For example, before embarking on his discussion of haiku (which will provide the framework for the account of notation), and in order to forestall impatience with the apparently technical considerations that will follow, Barthes insists that his concern is with a "interrogating a practice" (Barthes 2003: 49), a technique, or - key word - a gesture. But he adds that 
for him every action, technique or gesture has its own ethos and ethics. And thus he claims that his account of haiku as an act of notation is an investigation of the intersection of the aesthetic and the ethical. Whatever intellectuals may think, an interest in the technical aspect of writing, in how novelists gather their materials, organise their lives, and so forth, is for Barthes an interest in the ethical. Because, he goes on to say, the privileged field where the aesthetic (in the shape of techniques and gesture) and the ethical coincide, is in the minutiae of the everyday, the domestic realm. Perhaps the desire to write a novel is the desire to partake in a 'domestic' practice of writing. Just as Proust compared his novel in progress to the dress the seamstress cuts and pieces together, so Barthes casts himself in the role of a housewife, anxious to get the right ingredients for his homemade offering (Barthes 2003: 51).

A discussion of haiku occupies the central core of the first lecture course on La Préparation du roman in 1978-1979. Eight of the thirteen sessions are devoted to haiku, following three introductory sessions. Two entire sessions are devoted to conclusions, and it is here that what Barthes now calls "the daily practice of notation" (Barthes 2003: 137) becomes the central focus. This helps us to understand that everything Barthes says about haiku, the many traits he progressively elucidates, are related to the desire to talk about a practice of capturing present experience, and about the place of such a practice in the process of writing a novel.

In embarking on his discussion of haiku Barthes offers this definition of "my haiku":

haiku $=$ the exemplary form of the Notation of the Present $=$ a minimal act of enunciation, a form that has maximal brevity, the atom of a sentence that notes (marks, homes in on, glorifies, endows with fama) a minuscule element of 'real', present, concomitant life. (Barthes 2003: 53)

Barthes concedes that this definition is not canonical: he is talking about "my haiku", and he defends the overall principle of his lecture course whereby the subject (not the narrow narcissistic ego, but the voice of subjectivity) is allowed to be voiced, uncensored. He also concedes that the haikus to which he responds have been translated into French (he lists the various anthologies he quotes). The material parameters of haiku: three lines, a fixed number of syllables, tenuous presence on the page, are all ones he responds to in mediated form, 
and moreover via haiku's written rather than spoken forms (in Japan they are often read aloud).

Barthes's slow unfolding of the traits he identifies with haiku proceeds through a series of five rubrics:

(1) In The Desire for Haiku (Barthes 2003: 61-66) Barthes talks about the way haiku is a desirable or desire-bearing form, because in Japan ordinary people want both to write them and to read them. Haiku writing is a daily activity which fits in with the way haikus capture "a vibration of the world". Barthes accounts for the happiness haikus induce by citing their unhierarchical quality, their acceptance of what seems futile and tenuous. A haiku can talk about anything: it posits "the emergence of absolute immediacy", the co-presence of contingent elements. In a haiku the co-presence of items is not metonymic, antithetical, or causal: we are confronted with "a neutral consecutiveness". Haikus circulate in a community, playing down authorship, authority, possession. Haikus, Barthes says, posit "a quintessence of subjectivity", but not an author. A haiku belongs to anybody. And thus, Barthes affirms, "haiku is Desire, in so far as it circulates". Haiku is "made at life's own level, without remainder".

(2) In Le Temps qu'il fait (Barthes 2003: 66-84) Barthes starts from the idea that the only rule regarding the content of a haiku is that it should contain a reference to the season. This links what is placed before us, in a haiku's three brief lines, with the cosmos: not via description, but by summoning up directly the essence of the season itself, the essences of summer or autumn. Barthes connects this with references to the weather, and he bemoans the poverty of French where the same word, temps, is used for the English words time and weather. Yet he argues that the way the French language gets round this, via the expression 'le temps qu'il fait', when referring to the weather, adding a modal verb (with the verb faire - 'to do 'or 'to make'), shows that what is at stake when we refer to weather conditions is "the active relation of the subject and the present" (Barthes 2003: 71). A remark to a neighbour on the subject of weather is not just phatic but existential: it alludes to the "subject's sense of being, to the pure and mysterious sensation of living" (Barthes 2003: 72). ${ }^{3}$ In adverting to "le temps qu' $i l$ fait" haiku tends towards what Barthes calls "the individuation of the hours of the day" (Barthes 2003: 74).

See also Le Plaisir du texte (Barthes 2002: 252). 
Haikus always aim at the particular rather than the general: homing in on variations of weather endows a single day with variegation, a range of nuances, "a mottled, differentiated range of intensities" (Barthes 2003: 75). In a haiku, each hour of the day is a level of sensitivity. Haiku is a discourse that articulates states and levels for which there are no set words. At stake here is a principle that Barthes, citing Deleuze's recent work, calls Individuation or Nuance. Individuation is a notion that links irreducible singularity, "la nuance fondatrice', to particular moments, to weather, colour, phenomena. On this view, subjectivity (Barthes cites Nietzsche and again Deleuze) is essentially mobile, not fluctuating but constituted by a network of mobile points: subjectivity is not like a river, even a changing one, but a mutability that is discontinuous (and yet smooth [aheurtée]). Ambivalent, or dialectical, individuation shores up the subject in its individuality, its sovereignty, but at the same time "undoes" (défait) the subject, multiplies it, pulverises it, absents it (Barthes 2003: 79).

This makes it clear that what is at issue in Barthes's account of haiku as notation is the status of the subject. And he goes on to make a range of comments that connect nuance to a poetics of emptiness, to difference, always with weather, "le temps qu'il fait", on the horizon. Drawing on Blanchot's readings of Mallarmé, Barthes links haiku and indeed "all notation to a falling back on one's native impressions, a route back to the sheer sensation of life, the feeling of existence" (Barthes 2003: 84). It is worth noting that in this section Barthes quotes passages on exchanges to do with weather from a diary he kept in July and August 1977 in his summer retreat in the Basque country. The diary was one of the forms Barthes toyed with in his quest for a literary form in which to channel his desire to write and his passion for the present. In an important essay, Délibération, he discusses the reasons why he judged his experiment in diary writing to have been a failure (Barthes 2002, V: 668-681).

(3) Barthes considers next haiku's relation to the 'Instant' (Barthes 2003: 84-93). He stresses that the dimension of time haiku grasps or saves is not the past but the present: "Time is saved right away [tout de suite] [through] a concomitance of the note (of writing) and of what incites it" (Barthes 2003: 85) — what he will further on call the notandum — the thing to be noted. Paradoxically, 'Notatio (the fact of noting something down)' - the Latin word Notatio underscoring the fact that Barthes construes it both as a practice (exemplified by haiku) 
and as a rhetorical strategy like disposition or elocution - is also linked to the desire to remember. In fact haiku, and notation in general, convert immediate sensation into memory:

This uncompromisingly pure Instant, which seems to resist any type of duration, any kind of return, any setting aside, any freezing (this absolutely fresh Instant, as if one were eating the noted thing, straight from the tree, like an animal grazing on the living grass of sensation), this Instant also seems to say: to remind me - when I reread. An Instant that aspires to be a Treasure: Tomorrow: memory. This contradiction would express itself as follows: haiku [involves] a new and paradoxical category: 'immediate memory' as if Notatio (the fact of noting) permitted one to remember there and then. (Barthes 2003: 86)

(4) Under the heading Pathos (Barthes 2003: 93-111) Barthes focuses on affect and emotion. In haiku, affect is linked to perception, not in the banal sense of a faculty, but as an action, an event. In 1970 Barthes had written a set of brief 'notations' of his experience in Morocco, which were only published posthumously under the title Incidents. The following year, in an essay on Pierre Loti, he further elaborated the notion of the incident and of what just 'falls', ideas he links with haiku in Empire of Signs:

The incident is simply what falls, softly, like a leaf, onto the page of life. It is this fleeting, weightless fold in the fabric of days; it is what can scarcely be noted: a sort of zero degree of notation, just enough to enable something to be written. (Barthes 2002, IV: 109)

In his lectures Barthes connects the idea of the incident to another of his abiding preoccupations: the presence of tangible objects (tangibilia) in literary texts. For Barthes, the "passage of the tangible" gives us "a flash of the referent" that can be linked to fantasy and desire (Barthes 2003: 95). Regarding emotion, Barthes notes that haikus display a localised emotiveness ('émoi ténu') marked by the frequent use of exclamatory syllables like 'oh', and 'ah', although he goes on to stress that discretion is a key characteristic of haiku. "Haiku", he writes, "is assent to what is [... ] a happy assent to fragments [éclats] of the real, to affective inflexions" (Barthes 2003: 111).

(5) In another rubric, The Reality effect (Barthes 2003: 113-127), Barthes considers "how haiku's way of saying produces a reality effect", a term referring to instances when language gives way to a 
sense of certainty that the real has been attained (Barthes 2003: 113). ${ }^{4}$ In a few pages Barthes adumbrates the key arguments he will develop in Camera Lucida regarding the "this has happened" side of the photograph, and he proposes that haiku comes very close to the 'noem', the epistemology, of the photograph: 'ça a été': 'it has been'. And he goes on to suggest that while haiku articulates nuance and variegation, in showing how the world is infinitely divisible it also chooses a point at which to posit the real:

It is obvious that the world (the Notable, Notandum) can be infinitely divided (physicists do it) [...] so it follows that freeze-framing a notation has a certain arbitrariness [...] at a certain point [haiku affirms] that I have posited, affixed language. Yet, at what point in the descent into the infinitely subtle did I decide to affix language? (Or: why note this rather than that?). Perhaps the decision (and the little satori it provokes in reading) arises when metrics encounters a fragment of reality and makes a knot in it, stops it; a moment when the real is raised aloft by a combination of 5-7-5 syllables and allows this moment to be stated. (Barthes 2003: 119)

For Barthes this is what poetry does. And what it achieves is an experience he characterises by the word 'Tilt' (Barthes 2003: 123127), from the expression used in pinball, 'faire tilt', when the game is stopped momentarily by an abrupt gesture that sets all the alarms ringing: "a good haiku engenders a 'tilt' in the reader. But a haiku can also represent the tilt, the 'that's it': the brusque apparition of the referent in the stroll of life" (Barthes 2003: 123).

$$
* * *
$$

The two sessions of Barthes's lecture course where, after the focus on haiku, he opens up the discussion and works towards some conclusions, are together titled Passages (Barthes 2003: 137-161). Here he returns to the connections between "the fragmentary notation of the present" (Barthes 2003: 137) and the novel. How much 'notation' can be carried over into the novel? Barthes looks at this under four headings. He firstly considers notation "as a daily practice". Since it is an act that aims to capture a "sliver of the present" (Barthes 2003: 137 ) as it strikes you, notation poses a number of practical problems.

4 Cf. the famous essay L'effet de réel (Barthes 2002, III: 25-32). 
Barthes explains that his own practice involves always being equipped with a retractable biro (no need to take the cap off) and a pocket notebook. The 'copeau' or sliver consists in what he calls "my personal, inner scoops (scoop: spade, sheath, the action of scooping, a grab, a round-up, a first flowering)", which he wants to gather on life's very surface (Barthes 2003: 137). Suddenness, and a sense of kairos, the opportune moment, are key here: and so notation is a kind of reportage, not directed at 'la grosse actualité' (the big news), but at, 'my own little news'. Thus the impulse to note is unpredictable and notation is essentially "an outdoor activity — not the desk but the street, the café, with friends" (Barthes 2003: 137). Barthes's practice is to make what he calls a notula, often just one scribbled word, in his notebook, and then later to turn this into a nota by expanding it into a sentence on an index card. "Notable phenomenon: I forget the idea if I don't make a mark (notula) however elliptical; equally, once I've registered the nota I clearly remember the idea as a whole and even its form (its sentence)" (Barthes 2003: 137). Another practical consideration is making oneself available ('disponible'): noting things as they come up in life ('à même la vie') requires time and also what Freud called 'floating attention'. Barthes also observes that notation can become like a drug, or a mother from whom we are reluctant to be weaned, and he links this to Protestantism (citing Gide and Amiel as autobiographical diarists) since notation involves direct contact with the truth rather than mediation. Notation involves the "direct articulation of the thinking subject and the sentence-making subject" (Barthes 2003: 139).

Next are 'The levels of notation'. Reiterating a point he has often made elsewhere, that "meaning depends on the level or scale of perception" (Barthes 2003: 140), so that if you were to blow up five square centimetres of a Cézanne painting you would have a Nicolas de Staël canvas - Barthes argues that homing in on the minuscule does not necessarily imply brevity: in Proust for example the experience of the tenuous often leads to long flights of investigative prose.

He then goes on to consider what he calls the unit of notation, the notandum, and the various roles it can play (the various "justifications" it can receive). A Functional role, as when a character's minor trait "serves to indicate something necessary to the system of the Story" (Barthes 2003: 142). A Structural role, where the notandum is determined not by its content but by the rhythm of its appearance, 
its infrequency for example, or its very futility. A Symbolic role, as when the thing noted is a sign of something else (as example Barthes gives a long citation from Kafka). An Aesthetic role: here Barthes cites an incident from his own recent life, when, waiting for a bus in Paris he had seen a woman with a curious way of walking. In this instance the notandum was aesthetic because a particular type of sentence structure was required in order to register the impression it gave. The sentence had to be both contrastive and exclamatory, something like: "well, if a man walked like that he'd be called effeminate" (Barthes 2003: 144).

Summing up the question of levels, Barthes argues that, in formal terms, as a 'forme brève', notation is what cannot be summarised. A notation is a syntagm, a basic unit of signification. Barthes then posits that the brusque emergence (surgissement) of a notation is that of a sentence: the impulse, the jouissance of notation, is that of producing, or hatching, a sentence. Observing that a whole course could be devoted to this, Barthes makes a series of remarks on the nature of the sentence, notably around the idea of "sentence fetishism" (associated with Flaubert), a condition where, like poor Emma Bovary, we become victims of the fatal allure of certain kinds of statement (Barthes 2003: 149). As a 'leurre', a 'blind', the sentence, he says, wipes out (scotomise) everything else (Barthes 2003: 149). And he cites holiday advertisements that make us see the white sand, the beautiful women, and the cocktails, but omit the airport hold-ups, the frightful crowds and the painful sunburn.

Finally, getting back to the novel "as Utopia, Fantasy, Sovereign Good" (Barthes 2003: 151) — or at least to the last and most important relay towards what he now calls the "modern nota" Barthes considers two final facets of notation, its quiddity, associated with Joyce, and its truth, associated with Proust.

Joyce's famous epiphanies were originally composed (in 19001903) to stand alone, but were then incorporated into his first novel Stephen Hero, itself a step on the way to Ulysses. In the same period, Proust went from the scattered writings of his early years to the vast continuum of $A$ la Recherche. Fascinated by these two instances of passage, of transition from notation to experimental novel, Barthes considers the Joycean epiphany, defined as "the sudden revelation of the quiddity - the whatness - of a thing" (Barthes 2003: 151), as a model for his own experimentation with the form he called the 'inci- 
dent'. Drawing on Richard Ellman's biography of Joyce, and quoting one of Joyce's texts, Barthes is fascinated by the fortuitous, discrete, spasmodic character of epiphanies, which depend on an artistic posture of receptivity and availability:

This Joycean experiment with epiphanies is very important to me, and corresponds exactly to my own search for a similar form, which I call the Incident: a form I experimented with in snatches in The Pleasure of the Text, Roland Barthes by Roland Barthes, A Lover's Discourse, an unpublished text (Au Maroc) [later Incidents], and my chronicles in the Nouvel Observateur. (Barthes 2003: 152)

The reference at the end is to a weekly page Barthes wrote for the famous French weekly news magazine, Le Nouvel Observateur, during more or less the exact duration of his lecture course (Barthes 2002, V: 625-653). As he lectured week by week on the difficulties of writing the present, probing, via haiku, the parameters of such an enterprise, Barthes was supplying his listeners at the Collège de France (who often read his weekly column on the way to his lectures), and a much wider readership of over half a million, with a sample of his own experimentation with the form he called the incident. Each weekly Chronique comprised an average of four separately titled and unconnected entries ranging from a few lines to a couple of substantial paragraphs. In each case Barthes formulated concretely his subjective reaction to things that had grabbed his attention that week, for example an encounter at the hairdresser's, media coverage of the collective suicides of a sect in Guyana, a rumour that mayor Chirac planned to outlaw busking, advertisements and health campaigns. The first Chronique appeared on 18 December 1978, two days after his third lecture. His final column would appear on 26 March 1979. But already in his last lecture, on 10 March 1979, where Barthes discusses Joycean epiphany, he adumbrates the terms in which, in his final column, he would announce the suspension of his Chronique, and explains why he deemed the search for an adequate form to have failed. What he says in the lecture is that a common property of the haiku, the epiphany, and the Incident is that they should posit "immediately signifying events", that they should eschew all commentary:

the difficulty of the haiku, the epiphany, and the incident is the constraint of not-commenting $[\ldots]$ the extreme difficulty (or courage) [lies in] not giving the meaning, any meaning; deprived of commentary, the inconsequentiality of 
the incident is laid bare, and to let this inconsequentiality stand is almost heroic. (Barthes 2003: 153)

Yet, Barthes explains, in view of the large circulation of Le Nouvel Observateur he had felt that "it was impossible not to give to each incident its moral" (Barthes 2003: 153). And thus (as he would enlarge in his final column in the magazine) his Chronique, in failing to let incidents speak for themselves, was a failure. In this instance Barthes had not found a form to match his ambitions. And he wonders if Joyce too, in abandoning his epiphanies in their original form, and bringing them into the framework of his novels, had not confronted the same problem of feeling that the Western reader needed interpretation and could not tolerate elliptical brevity.

In Proust's case, Barthes argues, the fragmentary moment that exists in a problematic relation with any established form, is not connected with the quiddity of things, but with what he calls "the truth of affect" (Barthes 2003: 155). This has an affinity with haiku and epiphany because for Barthes it is enshrined in what he calls "the moment of truth", a moment which, as in haiku, prompts the reaction: "That's just it!" (C'est ça), an experience of 'Tilt'. The moment of truth is readerly rather than writerly, and for Barthes it is associated supremely with two moments in fiction - the death of Prince Boltonski in War and Peace, and the death of the narrator's grandmother in A la recherche (this insistence on death is of course poignant given the death of Barthes's own mother which had prompted his decision to think about writing a novel). The essence of such moments for Barthes is their radically concrete nature, rendered through details such as the grandmother's gestures, or her ruffled hair, painstakingly combed by the servant Françoise (Barthes repeats the word concrete six times in one page of his lecture).

Moment of truth $=$ solidity, compactness, firmness of affect and writing, an indivisible block. The moment of truth is not an unveiling but on the contrary the sudden emergence of the uninterpretable, the last degree of meaning, of the 'after that there is no more to be said', hence the filiation with haiku and epiphany. (Barthes 2003: 159)

Not surprisingly perhaps, Barthes ends his lecture course on an ambivalent or pessimistic note. He suggests that even if one could devise a mode of reading that would be founded on receptivity to such mo- 
ments in fiction, they are in fact at odds with the novel itself. In the end, the possible convergence between notation, notandum, and the novel, anticipated and hypothesised all the way through La Préparation $d u$ roman, never takes place, the two curves remaining asymptotic.

In truth the Novel [...] with its long flow, cannot sustain 'truth' (that of the moment): this is not its function. I see it as something woven (= Text), a vast spreading canvas painted with illusions, blinds, invented things, 'fakes' if you like [...] punctuated, threaded with [rare] moments of truth that are its absolute justification [...] when I produce Notations, they are all 'true': I never lie (I never invent), but precisely, I do not accede to the Novel; the novel begins not with the false, but when one mixes without warning the true and the false: the absolute, glaring truth, and the brightly coloured brilliance of a falsity that stems from Desire and the Imaginary [...]. Perhaps managing to write a novel (this is the perspective - the vanishing point - of this lecture course) means ultimately accepting to lie. In the end, resistance to the novel, an incapacity for the novel (for this practice) is a moral resistance. (Barthes 2003: 161)

A fascination with notation - a way of grasping the 'third meaning' that eludes (or subverts) both denotation and connotation - is at the heart of Barthes's late work, and in discussing it explicitly in his penultimate lecture course Barthes drew together many strands of his thinking. The passion for notation can be linked to a number of 'turns' in late Barthes: an affective turn - towards intensities; an everyday turn, amplifying his abiding concern for everyday life; a turn towards the 'romanesque', the stuff of the novel, but without the alibis of fiction and narrative. The desire for notation accompanies and informs Barthes's quest for new modes of writing, as he sought, after years of reacting to avant-garde currents, to give his own creativity a proper outlet. Through autobiography; the simulation of a lover's discourse; diary writing; the incident, the chronique, and other 'formes brèves'; and ultimately through the photograph, Barthes sought to find a form that would realise his ambition of "writing the present".

The lure of notation is also connected with Barthes's fascination with lives, with the raw materials, the bits and pieces that human lives, considered outside any teleology, are made up of. In a famous state- 
ment in Sade, Fourier, Loyola Barthes called these bits and pieces stray facts, anecdotes, memorabilia - 'biographèmes', and in the last years of Barthes's life Proust was at the centre of this concern. When he went on to give his last set of lectures the following year, continuing the theme of preparing for the novel but going on to consider "the work as effort of will", Barthes included many biographèmes from the life of Proust and also from other favourite writers (Chateaubriand, Kafka, Flaubert), drawn from letters, diaries, and correspondence, as he sought to pin down how writers organise their lives, and their time, in order to write. This fascination with 'biographèmes', and with the stuff of lives, relates of course to Barthes's long-standing passion for details (fashion details for instance), and for variegation, difference of degree (which he called 'bathmologies' in Barthes by Barthes). He coined the term 'Marcellisme' to convey his curiosity about the life of Proust (or Kafka, or Flaubert) - fuelled by his enthusiasm for George Painter's biography of Proust. This can of course seem like quaint obscurantism. But when situated in the context of the project of grasping the present, and reflecting on the epistemology of notation, Barthes's obsession with the writer's life is a fascinating route into new ways of thinking about the human subject.

Ultimately, then, notation is the vehicle, the sounding-board, for the subject that seeks articulation in late Barthes, a subject whose voice we hear most clearly, not in Incidents or Chronique, but in Camera Lucida. Yet now that they have been published at last, and are beginning to receive the recognition they deserve, it is to the four series of Collège de France lectures that we should perhaps look for a glorious flowering of the Barthesian subject. Consisting in a stream of notations, gathered up into a series of "traits", labelled with a key word and then presented in a randomized, unhierarchical order, the "fantasmatic pedagogy" of the lectures confirmed the key place of notation, and the third meaning it registers, in the signifying economy of Barthes's work. If his search for a new kind of romanesque never burgeoned into anything resembling a novel it surely flourished here in the wonderful affective and intellectual feast his lectures provided for their audiences in the 1970s and for a new readership in the twenty-first century. 


\section{References}

Barthes, Roland 1988. Lettre de Roland Barthes. In: Hommage à Georges Perros. Quimper: Calligrammes.

- 2002. Oeuvres complètes, 5 vols. [Marty, Eric (ed.).] Paris: Seuil.

- 2003. La Préparation du roman I et II. [Léger, Nathalie (ed.).] Paris: Seuil IMEC.

Perros, Georges 1961. Papiers collés. Paris: Gallimard.

Sheringham, Michael 2006. Everyday Life: Theories and Practices. Oxford:

Oxford University Press.

Записывая настоящее:

нотация в лекциях Коллеж де Франс Ролана Барта

В сових лекциях 1978-1979 гг в Коллеж де Франс Ролан Барт сосредотачивался на понятии 'la notation': запись прошедшего впечатления или события во время его случания. Настоящая статья анализирует виды нотащий, приведенные в лекциях (там виды нотаций связывались с хокку, эпифанией Джойса и прустовским импрессионизмом), связывая их с долговременным интересом Барта к онтологии разных видов обозначения. Нотащия находится в одном ряду с понятием «третьего значения» и более поздними терминами «инцидент» и «романный» и кажется центральным в проявившимся в поздних работах Барта интересе к аффекту, субъективности и индивидуальности. Так как нотация связана с фантазией написания романа, то это понятие отзывается и в «призрачной педагогике» бартовских лекций, где все идеи развиваются в сверхличном стиле посредством нагромождения различных не связанных между собой элементов. Бартовский децентрализованный, действующий аффективно субъект говорит именно в смысле нотации.

\section{Olevikku kirjutades: ülestähendamine Barthes'i Collège de France'i loengutes}

Oma 1978.-1979. aasta loengutes Collège de France'is keskendus Roland Barthes mõistele 'la notation' (inglise keeles 'notation'): mööduva mulje või sündmuse üles tähendamine märkmikusse selle aset leidmise ajal. Käesolev artikkel analüüsib ülestähendamise liike, nii nagu nad loengutes välja toodud on (loengutes on ülestähendamise liike seostatud haiku, Joyce'i epifaania ja prustiliku impressionismiga), sidudes neid Barthes'i 
pikaaegse huviga erinevate tähistusviiside ontoloogia vastu. Ülestähendamine kuulub samasse ritta 'kolmanda tähenduse' mõiste ning hilisemate terminitega 'intsident' ja 'romaanilik' ning paistab sellisena olevat keskne Barthes'i hilistes töödes väljenduvas huvis afekti, subjektiivsuse ja individuaalsuse vastu. Et ülestähendamine on seotud romaani kirjutamise fantaasiaga, kõlab see mõiste vastu ka Barthes'i loengute 'kummituslikus pedagoogikas', kus kõiki ideid arendatakse üliisiklikus stiilis erinevate omavahel mitte seotud elementide kuhjamise läbi. Barthes'i afektide ajel toimiv ja detsentraliseeritud subjekt leiab väljenduse just nimelt ülestähendamise mõistes. 